\title{
A screen for hydroxymethylcytosine and formylcytosine binding proteins suggests functions in transcription and chromatin regulation
}

Mario Iurlaro ${ }^{1}$, Gabriella Ficz ${ }^{2 *}$, David Oxley ${ }^{3}$, Eun-Ang Raiber ${ }^{4}$, Martin Bachman ${ }^{4,5}$, Michael J Booth ${ }^{4}$, Simon Andrews ${ }^{7}$, Shankar Balasubramanian ${ }^{4,5,6}$ and Wolf Reik ${ }^{1,8,9^{*}}$

\begin{abstract}
Background: DNA methylation $(5 \mathrm{mC})$ plays important roles in epigenetic regulation of genome function. Recently, TET hydroxylases have been found to oxidise $5 \mathrm{mC}$ to hydroxymethylcytosine $(5 \mathrm{hmC})$, formylcytosine $(5 \mathrm{fC})$ and carboxylcytosine $(5 \mathrm{caC})$ in DNA. These derivatives have a role in demethylation of DNA but in addition may have epigenetic signaling functions in their own right. A recent study identified proteins which showed preferential binding to 5-methylcytosine $(5 \mathrm{mC})$ and its oxidised forms, where readers for $5 \mathrm{mC}$ and $5 \mathrm{hmC}$ showed little overlap, and proteins bound to further oxidation forms were enriched for repair proteins and transcription regulators. We extend this study by using promoter sequences as baits and compare protein binding patterns to unmodified or modified cytosine using DNA from mouse embryonic stem cell extracts.

Results: We compared protein enrichments from two DNA probes with different CpG composition and show that, whereas some of the enriched proteins show specificity to cytosine modifications, others are selective for both modification and target sequences. Only a few proteins were identified with a preference for 5hmC (such as RPL26, PRP8 and the DNA mismatch repair protein MHS6), but proteins with a strong preference for $5 f C$ were more numerous, including transcriptional regulators (FOXK1, FOXK2, FOXP1, FOXP4 and FOXI3), DNA repair factors (TDG and MPG) and chromatin regulators (EHMT1, L3MBTL2 and all components of the NURD complex).
\end{abstract}

Conclusions: Our screen has identified novel proteins that bind to $5 \mathrm{fC}$ in genomic sequences with different $\mathrm{CpG}$ composition and suggests they regulate transcription and chromatin, hence opening up functional investigations of $5 \mathrm{fC}$ readers.

\section{Background}

Levels of $5 \mathrm{hmC}$ in DNA (and where known $5 \mathrm{fC}$ and $5 \mathrm{caC}$ ) vary between different mammalian tissues and are highest in ES cells and neural tissues [1-5]. In situations where oxidative derivatives of $5 \mathrm{mC}$ are implicated in demethylation of DNA, such as in pluripotent stem cells, early embryos and germ cells, there may be rapid turnover of these modifications through a combination of further oxidation, DNA replication, excision repair by

\footnotetext{
*Correspondence: g.ficz@qmul.ac.uk; wolf.reik@babraham.ac.uk

${ }^{2}$ Centre for Haemato-Oncology, Barts Cancer Institute, Charterhouse Square, London EC1M 6BQ, UK

'Epigenetics Programme, Babraham Institute, Babraham Research Campus, Cambridge CB22 3AT, UK

Full list of author information is available at the end of the article
}

TDG, and potentially deamination or decarboxylation [6-8]. In other tissues, especially those with non-dividing cells such as neural tissues, the modifications could potentially be more stable and might thus be used as epigenetic signals for genome function [9-11]. A variety of proteins that bind to histone modifications or to methylated DNA (methyl binding domain proteins (MBDs)) have been described and have a role in interpreting these epigenetic signals for the regulation of transcription, replication, DNA repair or other functions of the genome [12-14]. Recently, MBD3 and MECP2 have been shown to be able to bind 5hmC (MBD3 weakly so) in addition to $5 \mathrm{mC}$, opening up the possibility that these proteins may also be able to interpret the $5 \mathrm{hmC}$ signal, for example, in the regulation of transcription or chromatin $[15,16]$. A recently published unbiased screen 
[11] has identified and validated a number of proteins with specific binding to $5 \mathrm{mC}$ and its oxidised forms but the use of a single DNA probe overlooks the possibility that proteins in a cellular context might have a combined preference for both DNA modification and sequence context. Indeed some of the proteins identified as specific for a DNA modification are cell-type specific, suggesting a complex protein interaction network operating in modulating the intrinsic ability to bind to DNA modifications.

\section{Results and discussion}

We established a proteomics screen for $\mathrm{C}, 5 \mathrm{mC}, 5 \mathrm{hmC}$ or $5 \mathrm{fC}$ binding proteins based on modifications of published protocols [17]. Briefly, PCR probes were made corresponding to the promoter regions of the Pax 6 and Fgfl5 genes (relative position to the gene is shown in Figure 1c and 1d). Both of these genomic regions are enriched for $5 \mathrm{hmC}$ in $\mathrm{mESCs}$, and their corresponding gene expression is associated with changes in the relative levels of $5 \mathrm{mC} /$ $5 \mathrm{hmC}$ in control relative to Tet1 siRNA-treated cells [18]. Modified cytosines were incorporated during PCR and the probes were then incubated with nuclear protein extracts from mESCs (E14 ES cells cultured in Serum/LIF conditions). Proteins which bound to the probes were eluted and identified by mass spectrometry (Figure 1a and full table in Additional file 1). We initially verified whether the screen was able to enrich the previously known $5 \mathrm{mC} /$ 5hmC binder NP95/UHRF1 [19]. Indeed the western blot in Figure 1b shows specific binding of the protein to both modifications. Our mass spectrometry results also confirmed the recently identified proteins specifically binding to $\mathrm{C}$ (KDM2B, CXXC5, BCOR) and 5mC (RFX1, MBD4) (Additional file 1 and [11]).

Having established a screen that was robust and identified known binders of both $5 \mathrm{mC}$ and $5 \mathrm{hmC}$, we systematically evaluated all binding proteins and included $5 \mathrm{fC}$ modified targets in the screen (Additional file 1, Figure 1c and d, Figures 2 and 3). Pull-downs were performed in triplicate for each DNA modification with both Pax6 and Fgf15 probes, and resulting values were analysed using a non-parametric Kruskal-Wallis ANOVA with a threshold sufficient to identify proteins where the replicates for one modification were consistently the most enriched against a random set of enrichments in the other pull-downs. The Venn diagrams in Figure 1c and 1d include only proteins with significant enrichment and show binding distribution to differentially modified probes. A detailed representation of relative binding of proteins to each modification in each target sequence is shown in Figures 2a and 3. Heatmaps were generated by unsupervised hierarchical clustering of the mass spectral counts for each protein (horizontal lines) binding to each modification in three replicate pull-downs, normalised by row mean subtraction. Protein enrichment is indicated in red (highly enriched) to green (under-enriched relative to mean). Some of the candidate proteins are highlighted on the right side of the heatmaps and the full list is shown in Additional file 2.

Of interest were proteins that bound only to unmodified C, such as BEND3, USF1, USF2, CXXC5 and KDM2B, perhaps reflecting a binding architecture that is disrupted by modifications on the DNA. Among proteins that showed specificity for $5 \mathrm{mC}$ are previously identified methyl-CpG binding proteins like MBD4 and RBPJ [20,21], but also TET1, OGT and interestingly a key pluripotency regulator ESRRB [22], which has not been previously identified as a $5 \mathrm{mC}$ binding protein (Figures 2 and 3). Only few proteins showed a strong preference for $5 \mathrm{hmC}$ (such as RBM14, PRP8 and RPL26 on Fgf15, MSH6 and PNKP on Pax6 probe, respectively). Similarly to Spruijt et al. [11] we also did not find MBD3 binding to $5 \mathrm{hmC}$ with higher affinity than to $5 \mathrm{mC}$ (as was previously reported by Yildirim et al. [15]). Instead, MBD3 showed selective binding to $5 \mathrm{mC}$ in the Pax6 target and to $5 \mathrm{mC} / 5 \mathrm{fC}$ in the Fgf15 target, in agreement with Spruijt et al. where MBD3 at high concentrations had higher affinity to $5 \mathrm{mC}[11,23]$. Our screen revealed that more proteins bind uniquely to $5 \mathrm{fC}$ than to other DNA modifications (barplots in Figure 1c and 1d). Notably, 21 proteins were found exclusively bound to the $5 \mathrm{fC}$ probes - 11 on the Fgf15 probe (among which are TDG, SIX4, ZSCAN21 and ZKSCAN3), 8 on the Pax6 probe (including MPG, FOXP4 and CRSP2) and 2 to both probes (FOXK2 and FOXI3). Many more proteins bound to $5 \mathrm{fC}$ preferentially (Additional files 1 and 2 and Figure 4a).

Gene ontology term enrichment comparing modification specific binders to the full set of identified proteins showed highly significant groups enriching with relevance to gene transcription and chromatin regulation among $5 \mathrm{fC}$ binders on the Fgf15 probe (Figure 2b). Association of $5 \mathrm{fC}$ with repressive transcription complexes was a surprising finding where, notably, all members of the core NuRD complex were enriched in the group of $5 \mathrm{fC}$ specific binding proteins (Figure 2a), although it is likely that some of the members of the complex are not direct $5 \mathrm{fC}$ binders but are enriched by secondary protein-protein interactions. This indicates that $5 \mathrm{fC}$ is more likely to be associated with gene repression. Interestingly, many of the proteins enriched for $5 \mathrm{fC}$ at the Fgf15 probe were enriched for $5 \mathrm{mC}$ too, as seen by the hierarchical clustering, strengthening the potentially repressive properties of $5 \mathrm{fC}$ especially in the context of a CpG island sequence. This was not the case with the Pax6 probe, which is not a $\mathrm{CpG}$ island (Figure 3 ). It remains to be seen if the presence of $5 \mathrm{fC}$ in CGIs has inhibitory functions, especially in the process of cell differentiation. Clustering of proteins enriching on the Pax 6 probe did not result in a similar grouping of $5 \mathrm{fC}$ and $5 \mathrm{mC}$ enriching repressive proteins and the $\mathrm{GO}$ analysis showed no significant enrichment for repressive complexes indicating that 


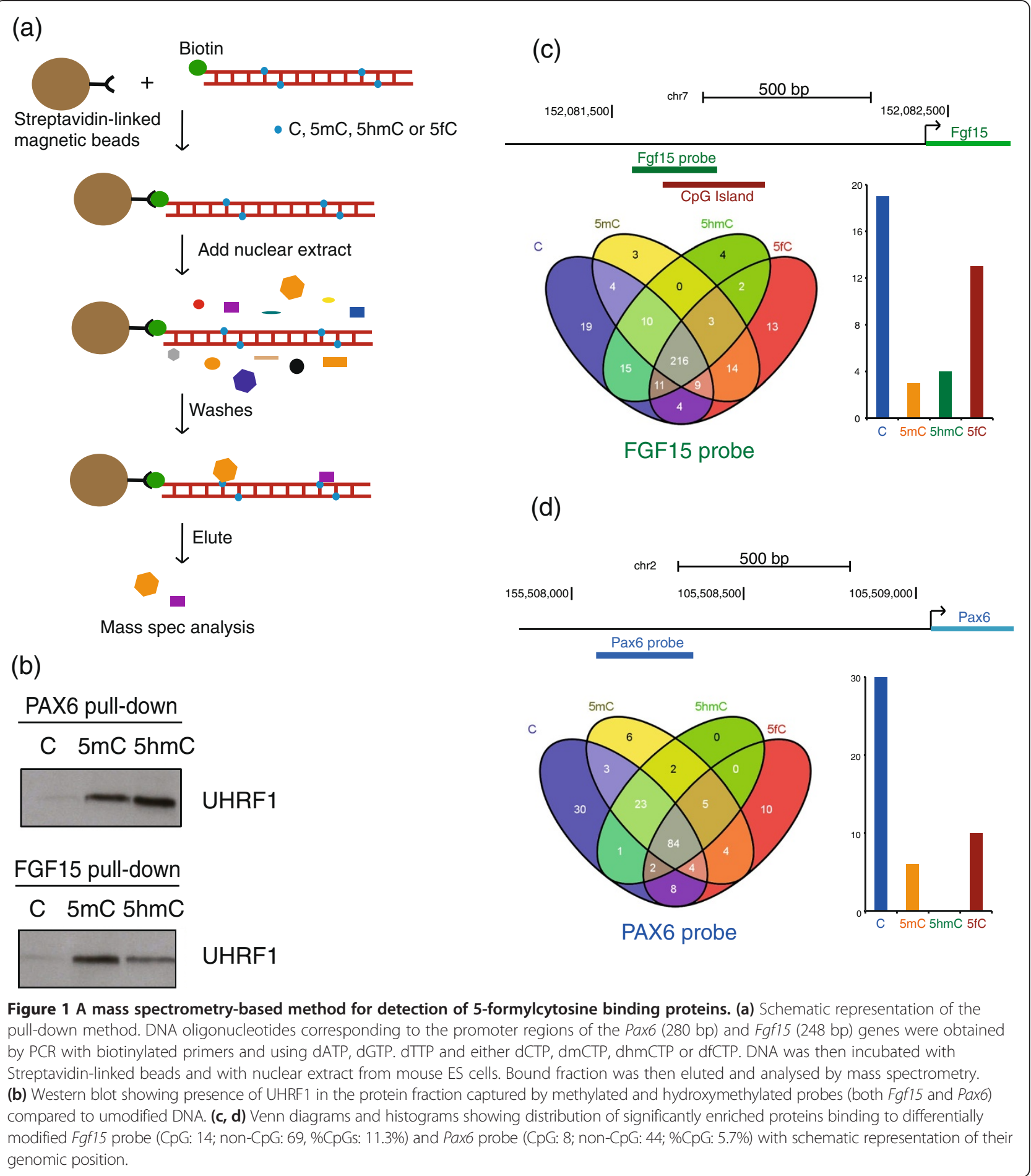

the DNA sequence of Pax6 might lack the DNA signatures of a typical CpG island therefore may not result in an inhibitory transcriptional signal in the presence of $5 \mathrm{fC}$. While our experimental system made use of a promoter CpG island (in Fgf15) these insights may also be applicable to intragenic $\mathrm{CpG}$ islands, which can have higher levels of DNA modifications [24]. The association between 5-formylcytosine and transcription has been investigated recently, resulting in its linkage variously with active or poised genes [25-27]. Our results potentially reinforce the idea that depending on context $5 \mathrm{fC}$ could have positive or negative effects on transcription. Nevertheless, some of the $5 \mathrm{fC}$ specific proteins were enriched with both DNA probes and are shown in Figure 4a. This comparison strongly 

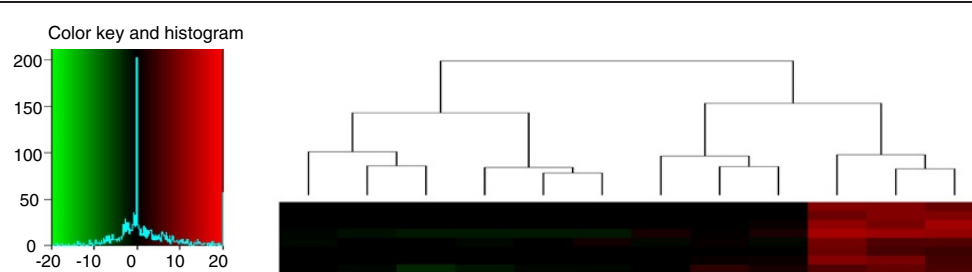

(a)
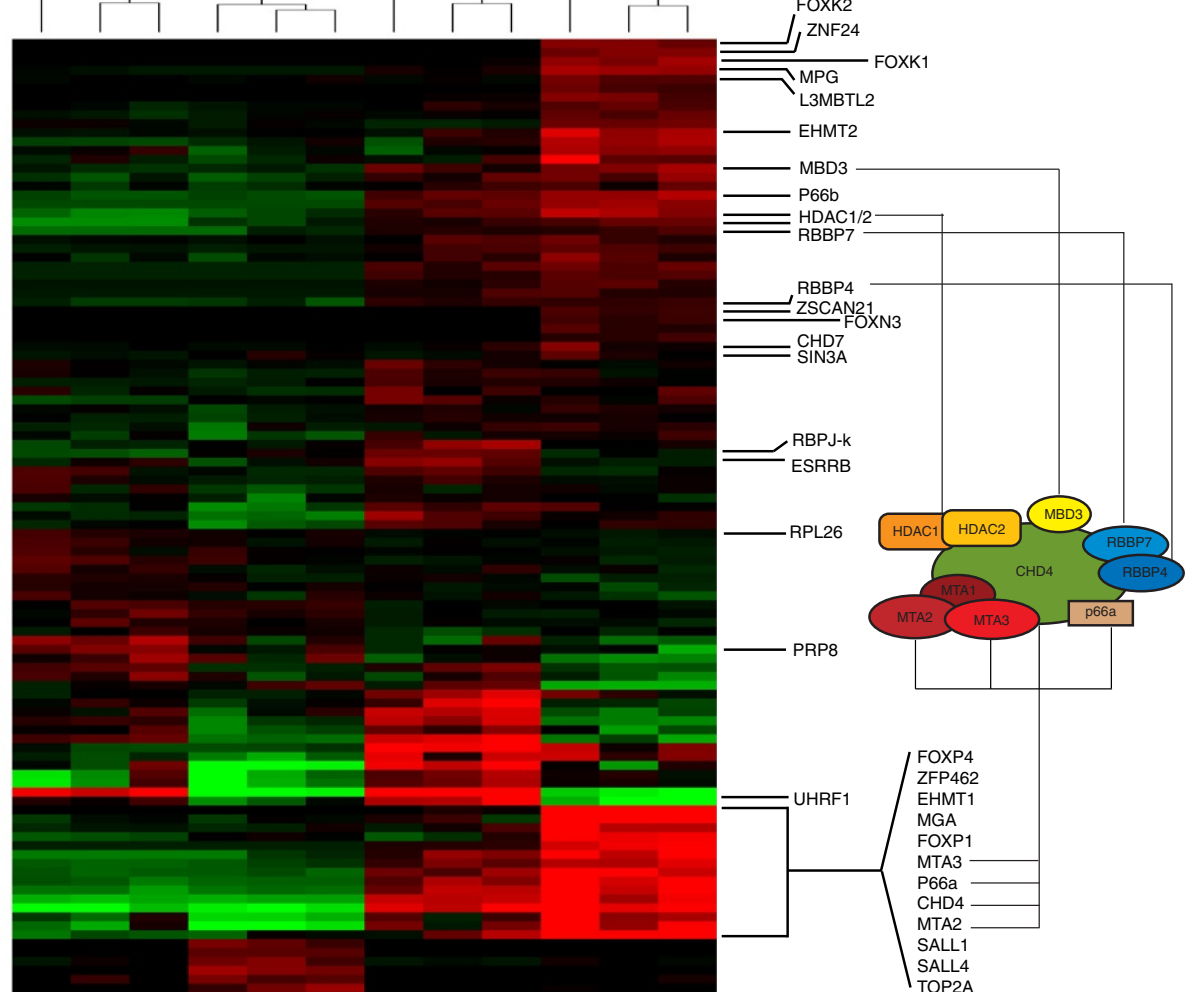

(b)

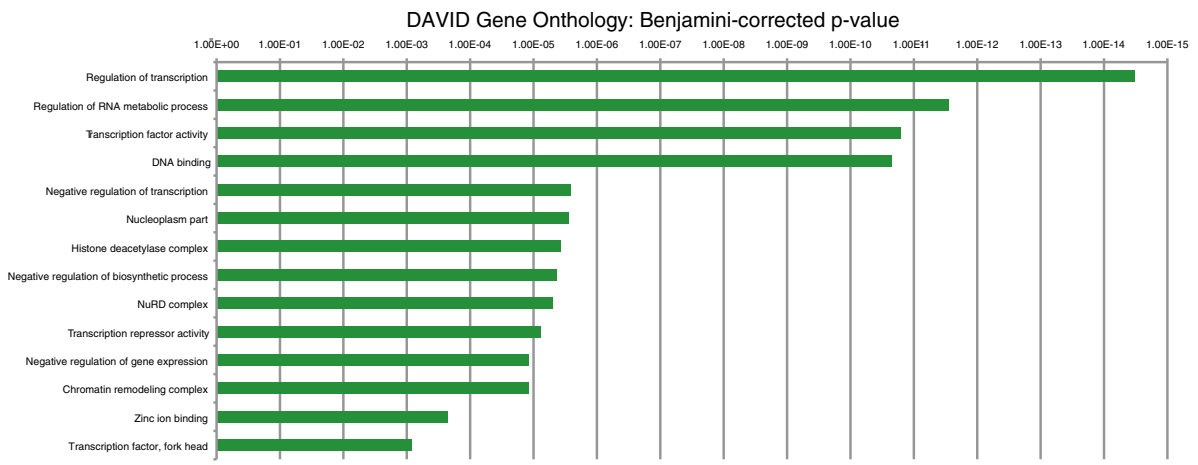

Figure 2 (See legend on next page.) 
(See figure on previous page.)

Figure 2 5-formylcytosine specific binders to Fgf15 probe are enriched for transcription factors and chromatin regulators. (a) Heatmap representation of the relative protein enrichment on the Fgf15 probe. Spectral count values for each replicate were analysed by testing the sample groups using a non-parametric Kruskal-Wallis $t$-test with a $P$ value cutoff of 0.1 . For heatmap display, additional filters for the size of absolute change between group means were applied, and the data for each gene were normalised by subtracting the median value for that gene across all experiments from the individual values. A cartoon highlights presence of all the component of the main core of the NuRD complex among the $5 f C$ binders. (b) Functional annotation enrichment analysis performed on $5 f C$ binders using DAVID shows enrichment for transcription

(mainly zinc-binding factors) and chromatin regulators. Results are expressed with their corresponding Benjamini-corrected $P$ value.

suggests that Fork head box domain containing proteins have $5 \mathrm{fC}$ binding properties. Gene ontology results for the other cytosine modifications for the two probes are included as Additional files 3 and 4.

In order to validate some of these candidate proteins for $5 \mathrm{fC}$ binding specificity, we performed ELISA with purified recombinant proteins and differentially modified Fgf15 probes. His-tagged isoforms of MPG, L3MBTL2 and ZSCAN21 were expressed in Sf9 insect cells using a Baculovirus system, and purified by immobilised metal ion affinity chromatography (IMAC). We found that all three proteins bound with higher affinity to $5 \mathrm{fC}$ compared to the other modifications on the DNA (Figure 4b). MPG is one of the proteins common for both DNA targets and showed a strong binding preference for $5 \mathrm{fC}$. In a recent study MPG was identified as a $5 \mathrm{hmC}$ specific binder but the data actually show some binding to $5 \mathrm{fC}$ as well [11], and considering different culturing conditions of ES cells (2i/LIF), post-translational modifications might modulate the binding of some proteins to their target [28]. Finally, we considered the possibility that the $5 \mathrm{fC}$ binding proteins might have a role in the excision of $5 \mathrm{fC}$ similar to TDG. We therefore tested this hypothesis by RNAi in ES cells (Figure 4c, Additional files 5 and 6). While knockdown of TDG (which is known to excise $5 \mathrm{fC}$ and $5 \mathrm{caC}[29,30]$ ) resulted in increase of $5 \mathrm{fC}$ and $5 \mathrm{caC}$ (as measured by mass spectrometry), knockdown of the other candidates had no effect. We therefore conclude that the majority of $5 \mathrm{fC}$ binding proteins identified in this screen are less likely to metabolize $5 \mathrm{fC}$, instead they are more likely to recognize $5 \mathrm{fC}$ as an epigenetic signal.

The preferential binding of TET1 to both $5 \mathrm{mC}$ (more strongly) and $5 \mathrm{hmC}$, compared to $\mathrm{C}$ (Figure 3 ) was interesting since the CXXC domain of TET1 has been shown to differ from that of other CXXC domain-containing proteins, lacking a typical 'KFGG' motif found in most of the family, with some studies showing its inability to bind DNA [31], and others suggesting that this peculiarity allows it to bind not only to unmodified and methylated DNA, but also to hydroxymethylated DNA [32,33]. This opens the possibility that the binding could be influenced by sequence context or protein modifications.

It was of particular interest that our screen identified a higher number of proteins that appear to preferentially bind to $5 \mathrm{fC}$ (Figure 1c,d) rather than to other modifications, an observation also reported in Spruijit et al. [11]. It is not immediately intuitive why there should be more proteins binding to $5 \mathrm{fC}$ than to $5 \mathrm{hmC}$. Of course this could depend on the tissue analysed and there might be more $5 \mathrm{hmC}$ binding proteins in neural cell types, for example, where the modification is relatively prevalent. Intriguingly, FOXK2 in addition to being a member of the forkhead box transcription factor family has been shown to bind to T:G mismatches in DNA but no enzymatic activity has been identified [34]. Another member of this family, FOXP1, a key transcriptional regulator in B cells and lung development was also identified as strong and specific $5 \mathrm{fC}$ binder in our screen. Recent reports have shown that an ES cell-specific isoform of FOXP1 is implicated in pluripotency regulation in ESCs by stimulating expression of pluripotency-related genes like Oct4, Nanog and Nr5a2 [35]. FOXP4, also enriched on both $5 \mathrm{fC}$ probes, is involved in development of the lung and is known to form homodimers and heterodimers with FOXP1, and to interact with NuRD components [36]. FOXK1 is a transcriptional regulator involved in myogenic regulation [37], while relatively little is known about the function of mouse FOXI3. Another transcription factor that appears to bind specifically to $5 \mathrm{fC}$ in our screen is ZSCAN21, a strong transcriptional activator that plays a role in both male and female meiosis $[38,39]$. The final protein in this category of transcriptional regulation linked with DNA repair is MPG, which is a base excision repair glycosylase known to excise modified bases resulting from alkylation damage. MPG was a highly specific binder for $5 \mathrm{fC}$ in our screen, while the human isoform bound strongly to $5 \mathrm{fC}$ in a HeLa sample extract providing an additional layer of confidence (data not shown); MPG has been identified as a interacting partner of MBD1 [40] and, intriguingly, its methyl-purine glycosylase domain structurally resembles the formyl transferase, C-terminal-like domain (IPR011034).

The last category of $5 \mathrm{fC}$ binders makes interesting connections with chromatin regulation through the polycomb and histone methylation pathways. In addition to the previously mentioned correlation between $5 \mathrm{fC}$ and the NuRD complex, components of another chromatin regulator complex, E2F6.com-1, were also identified as $5 \mathrm{fC}$ binders. In addition to MGA and CBX3, we isolated and verified L3MBTL2 as a $5 \mathrm{fC}$ binder, which is a putative polycomb protein which may bind to modified histones, while 


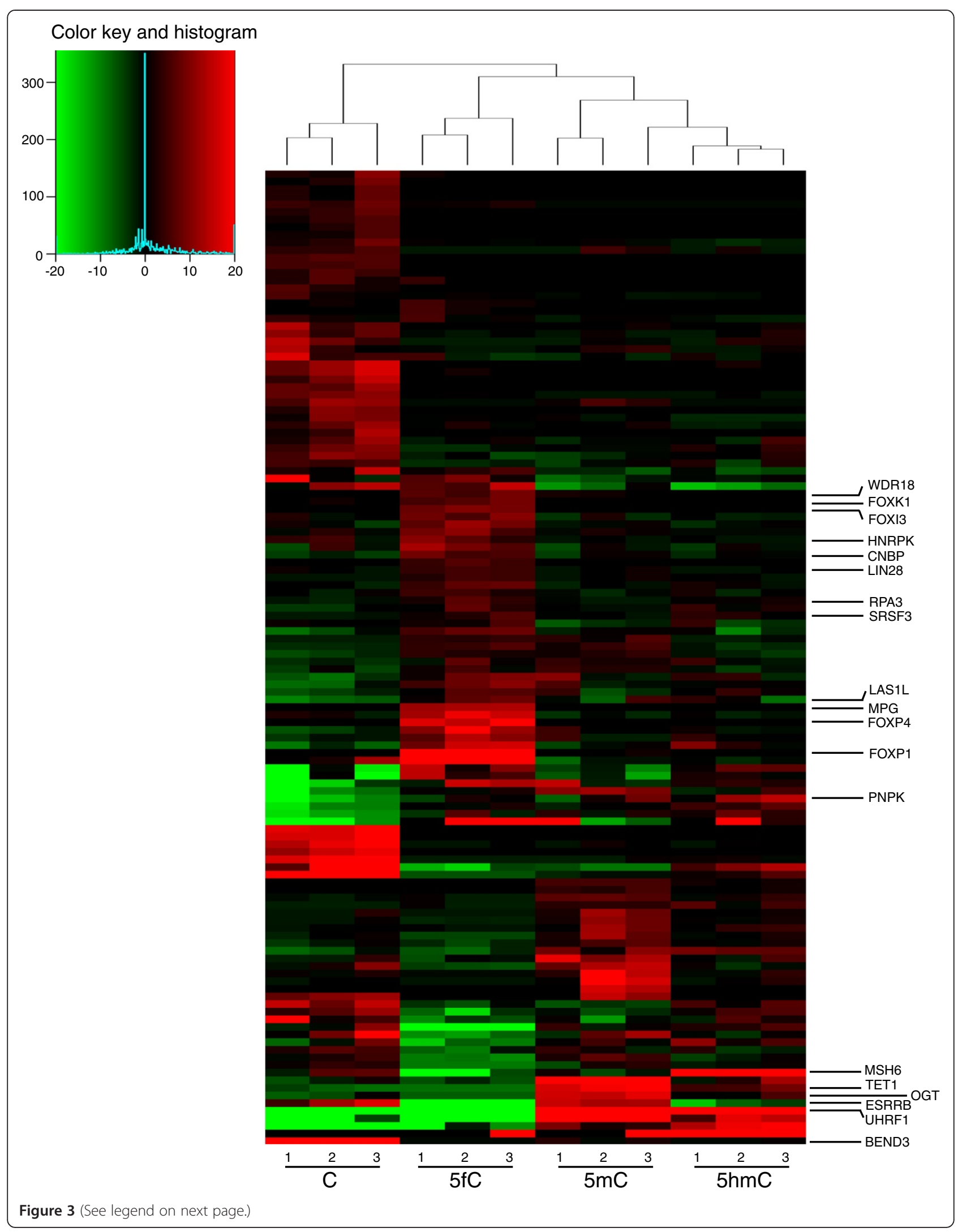


(See figure on previous page.)

Figure 3 Relative protein enrichment in pull-downs with the Pax6 probe. Heatmap representation of the relative protein enrichment on the Pax6 probe. Spectral count values for each replicate were analysed by testing the sample groups using a non-parametric Kruskal-Wallis $t$-test with a $P$ value cutoff of 0.1. For Heatmap display, additional filters for the size of absolute change between group means were applied, and the data for each gene were normalised by subtracting the median value for that gene across all experiments from the individual values.

EHMT1 is a euchromatin histone methyltransferase that methylates $\mathrm{H} 3 \mathrm{~K} 9$ to $\mathrm{H} 3 \mathrm{~K} 9 \mathrm{me} 1$ and me2, potentially providing a link between modifications in euchromatin that are intermediates between transcriptional repression and activation [41,42].

\section{Conclusions}

We have established a relatively simple and robust screen for proteins that bind $5 \mathrm{hmC}$ and $5 \mathrm{fC}$ in DNA. $5 \mathrm{fC}$ has so far been found in early embryos, embryonic stem cells and brain cortex, as well as in other major mouse organs like spleen, pancreas and liver [43]. The distribution of $5 \mathrm{fC}$ in ESCs depends on TDG and recent studies have linked it with the regulation of transcription, variously associated with active or poised genes [25-27]. Our screen has identified 5fC-binding proteins with functions in transcription and in chromatin regulation, particularly involving forkhead box domain transcriptional regulators and the NuRD (a)
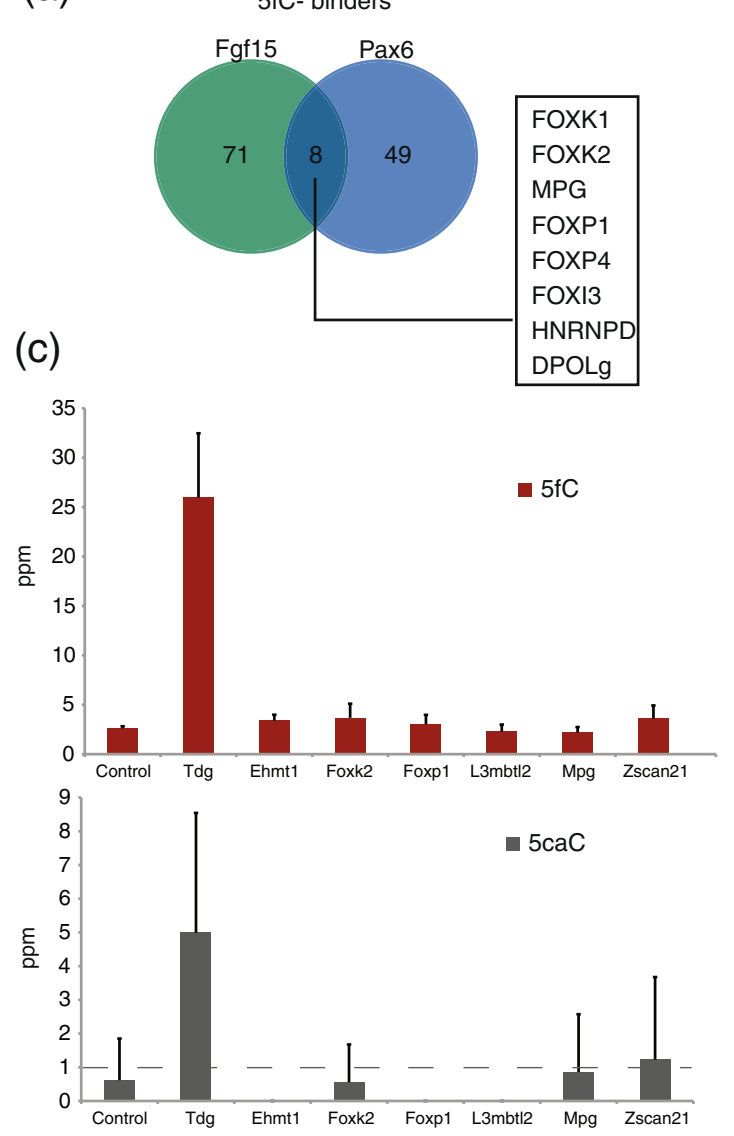

(b)

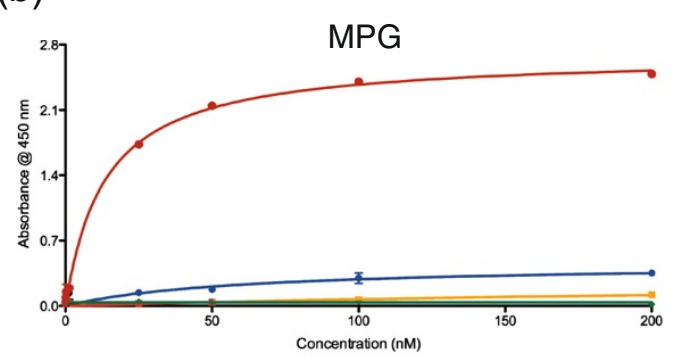

L3MBTL2
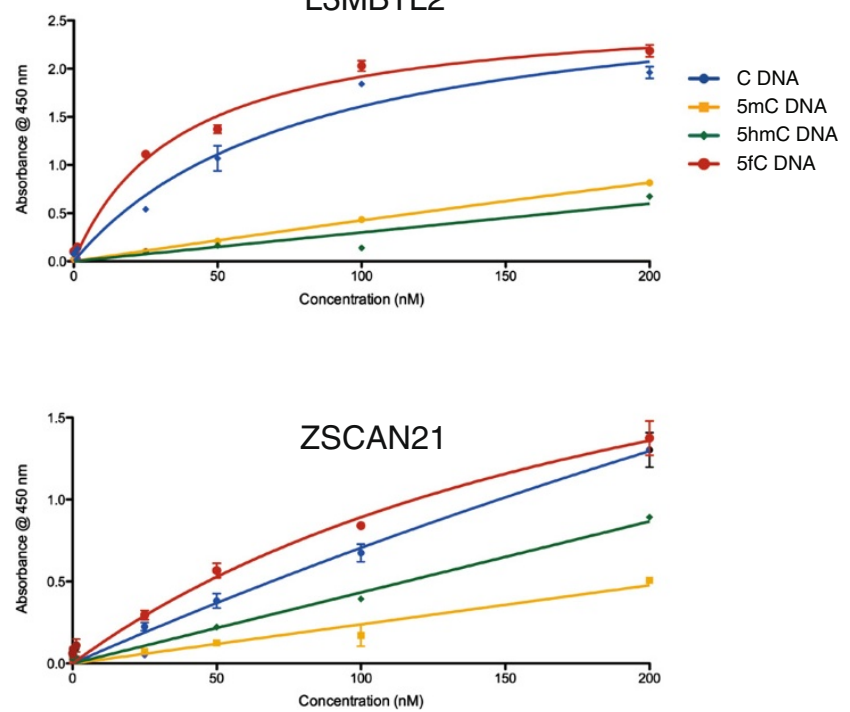

Figure 4 Validation and functional analysis of $\mathbf{5 f C}$ binding proteins. (a) Venn diagram illustrating overlap between $5 f C$ specific binders identified by the two different probes used. (b) ELISA assays performed with purified recombinant MPG, L3MBTL2 and ZSCAN21 proteins and differentially modified Fgf15 probe (blue = unmodified DNA; yellow = methylated DNA; green = hydroxymethylated DNA; red = formylated DNA). MPG (specifically bound to $5 \mathrm{fC}$ on both probes) shows strong selective binding for formylated DNA (Kd=13.4 $\pm 1.4 \mathrm{nM})$. L3MBTL2 (Kd=37.1 \pm 5.6 $\mathrm{nM}$ for $5 \mathrm{fC}$ and $\mathrm{Kd}=81.2 \pm 18.8 \mathrm{nM}$ for C) and ZSCAN21 show preference of binding. This could reflect the difference in DNA interaction between an enzyme and transcriptional regulators. (c) Mass spectrometry analysis of global 5-formylcytosine (red bars) and 5-carboxycytosine (grey bars) levels in J1 ES cells after three rounds of knockdown of potential $5 \mathrm{fC}$ binders, compared to cells transfected with non-targeting siRNA. Bars show average of four biological replicates with corresponding standard deviation, expressed as the number of modified cytosines per million of all cytosines. Dotted line indicates the limit of accurate quantification. 
complex. This suggests that $5 \mathrm{fC}$ may be both an intermediate in demethylation and an epigenetic signal in its own right. The dual potential of some of the proteins we have identified (FOXK2 in transcription and DNA repair, EHMT1 mediating between 5fC and H3K9 methylation) is particularly interesting and warrants future functional investigations.

\section{Methods}

\section{Cell lines and cell culture}

E14 ES cells (derived from the E14 cell line strain 129P2/ OlaHsd) were grown on a $\gamma$-irradiated pMEF feeder layer at $37^{\circ} \mathrm{C}$ and $5 \% \mathrm{CO}_{2}$ in complete ES medium (DMEM $4,500 \mathrm{mg} \mathrm{l}^{-1}$ glucose, $4 \mathrm{mM}$ l-glutamine and $110 \mathrm{mg} \mathrm{l}^{-1}$ sodium pyruvate, $15 \%$ fetal bovine serum, $100 \mathrm{U}$ of penicillin $/ 100 \mu \mathrm{g}$ of streptomycin in $100 \mathrm{~mL}$ medium, $0.1 \mathrm{mM}$ non-essential amino acids, $50 \mu \mathrm{M} \beta$-mercaptoethanol, $10^{3}$ U LIF ESGRO).

\section{Nuclear extraction}

Cells were washed with $1 \times$ PBS solution, detached adding trypsin at $37^{\circ} \mathrm{C}$ to the culture plate and centrifuged at $300 \times \mathrm{g}$ for $4 \mathrm{~min}$. The pellet was then washed in ice-cold $1 \times$ PBS twice and resuspended gently in 5 volumes of icecold 1 Cytoplasmic Lysis Buffer (Chemicon International ${ }^{\circ}$ ) containing $0.5 \mathrm{mM}$ DTT and 1/1,000 dilution of supplied protease inhibitor Cocktail. The solution was incubated on ice for $15 \mathrm{~min}$, centrifuged at $300 \times \mathrm{g}$ for $5 \mathrm{~min}$ at $4^{\circ} \mathrm{C}$, and the pellet was resuspended in two volumes of ice-cold $1 \times$ Cytoplasmic Lysis Buffer. Cells were lysed using a 27 -gauge needle and the nuclear fraction was isolated from the cytosolic portion by centrifugation at $8,000 \times \mathrm{g}$ for $20 \mathrm{~min}$ at $4^{\circ} \mathrm{C}$. Finally, the pellet was resuspended in two-thirds of the original cell pellet volume of ice-cold Nuclear Extraction Buffer (Chemicon International ${ }^{\circ}$ ) containing $0.5 \mathrm{mM}$ DTT and 1/1,000 dilution of supplied protease inhibitor cocktail, incubated on orbital shaker for $60 \mathrm{~min}$ at $4^{\circ} \mathrm{C}$, and centrifuged at $16,000 \times \mathrm{g}$ for $5 \mathrm{~min}$ at $4^{\circ} \mathrm{C}$. The nuclear extract was then aliquoted and stored at $-80^{\circ} \mathrm{C}$.

\section{DNA probes}

The probes were obtained by PCR amplification of genomic region corresponding to the promoters of Pax6 (280 bp) and Fgf15 (248 bp) genes using DreamTaq ${ }^{\text {tm }}$ DNA Polymerase (Fermentas). The primers used in the reaction were:

Pax6-F (Biotinylated):

ATTCCCAAAGCAAGCAGAAG

Pax6-R: ACTGTTGACTTTGTGGCCTAGA

Fgf15-F (Biotinylated):

TTTCTTTCAGGCAGGGGAAT

Fgf15-R: TTGAGAAGGGTGGACTGACC

\section{Pull-down}

The pull-down assay was carried out using Dynabeads ${ }^{\circ}$ M-280 Streptavidin (Invitrogen ${ }^{\mathrm{Tm}}$ ). For each sample, $2 \mu \mathrm{L}$ of beads were washed in buffer PBT $(1 \times$ PBS, $0.1 \%$ Triton $\mathrm{X}-100)$, and incubated with $50 \mathrm{ng}$ of biotinylated DNA in $200 \mathrm{uL}$ of PBS, overnight at $4^{\circ} \mathrm{C}$. The beads were then washed three times in $\mathrm{PBT}$ and twice in buffer D-T (0.2 mM EDTA, 20\% Glycerol, $20 \mathrm{mM}$ Hepes- $\mathrm{KOH}$ $\mathrm{pH}$ 7.9, $0.1 \mathrm{M} \mathrm{KCl}, 1 \mathrm{mM}$ DTT, $1 \mathrm{mM}$ protease inhibitor PMSF, 0.1\% Triton X-100), and incubated with $50 \mu \mathrm{g}$ of nuclear extract for $15 \mathrm{~min}$ at $4^{\circ} \mathrm{C}$ in incubation buffer (0.05 mM EDTA, 5\% Glycerol, 5 mM Hepes-KOH pH 7.9. $150 \mathrm{mM} \mathrm{KCl}, 1 \mathrm{mM}$ DTT, $1 \mathrm{mM}$ protease inhibitor PMSF, $0.025 \%$ Triton X-100 in PBS). The beads were washed six times in Buffer D-T, once in PBS and eluted in 1X LDS Loading buffer boiling at $95^{\circ} \mathrm{C}$ for $5 \mathrm{~min}$. The eluted fraction was separated from the beads and finally analysed by mass spectrometry.

RNAi knockdown of Mpg, Tdg, L3mbtl2, Zscan21, Ehmt1, FoxK2 and FoxP1 in ES cells

Transfections of Dharmacon siGENOME SMARTpool against mouse $T d g$ (catalogue number M-040666-01; gaagugcaguauacauuug, gaguaaagguuaagaacuu, caaagaag auggcuguuaa, gcaaggaucugucuaguaa) and siGENOME ON-TARGETplus siRNA against $M p g$ (catalogue no. J060513-11; ccggcuaggaccagaguuu), L3mbtl2 (catalogue no. J-065321-12; uuacugacuggaagagcua), FoxP1 (catalogue no. J-065400-09; gagcaugcgcuggacgaua), Ehmt1 (catalogue no. J-059041-12; gagcacagguggauccgaa), Zscan21/Zipro1 (catalogue no. J-048225-09; cuagagauaucccguaaga), FoxK2 (catalogue no. J-064514-12; ccagagcucaagcgaguua) were done with Lipofectamine 2000 according to the manufacturer's instructions. Cells were harvested after three rounds of transfection for DNA/RNA isolation.

\section{Mass spectrometry}

Eluted proteins were run a short distance (approximately $5 \mathrm{~mm}$ ) into an SDS-PAGE gel, which was then stained with colloidal Coomassie stain (Imperial Blue, Invitrogen). The entire stained gel pieces were excised, then destained, reduced, carbamidomethylated and digested overnight with trypsin (Promega sequencing grade, $10 \mathrm{ng} / \mu \mathrm{L}$ in $25 \mathrm{mM}$ ammonium bicarbonate) as previously described [44]. Aliquots of each of the resulting tryptic digests were analysed by LC-MS/MS on a system comprising a nanoLC (Proxeon) coupled to a LTQ Orbitrap Velos mass spectrometer (Thermo). LC separation was achieved on a reversed-phase column (Reprosil C18AQ, $0.075 \times 150 \mathrm{~mm}$, $3 \mu \mathrm{m}$ particle size), with an acetonitrile gradient $(0-35 \%$ over $60 \mathrm{~min}$, containing $0.1 \%$ formic acid, at a flow rate of $300 \mathrm{~nL} / \mathrm{min}$ ). The mass spectrometer was operated in data-dependent acquisition mode, with an acquisition cycle consisted of a high resolution precursor ion spectrum over 
the $\mathrm{m} / \mathrm{z}$ range $350-1,500$, followed by up to 20 CID spectra (with a $60 \mathrm{~s}$ dynamic exclusion of former target ions). Mass spectrometric data were searched against a database generated from the mammalian entries in Uniprot 2011.09 by concatenation of the forward and reversed sequences, using Mascot (Matrix Science) and the search results were processed using Scaffold software (Proteome Software Inc.). Criteria for protein identification were: minimum of two peptides, each with a probability of $>50 \%$ and an overall protein probability of $>99 \%$, which gave a protein false discovery rate of $0.4 \%$. The mass spectrometry proteomics data have been deposited to the ProteomeXchange Consortium [45] via the PRIDE partner repository [46] with the dataset identifier PXD000524.

\section{Western blot}

Pulled-down proteins were eluted from beads in LDS Loading buffer, boiled and run on NuPAGE ${ }^{\oplus}$ Novex 4-12\% Bis-Tris Gel $1.0 \mathrm{~mm}\left(\right.$ Novex $\left.^{\odot}\right)$. Proteins were transferred on a nitrocellulose membrane using iBlot ${ }^{\oplus}$ Blotting System (Life Technologies), membrane was blocked overnight in PBS-0.1\%Tween (PBST) containing 5\% BSA (blocking buffer). Primary antibody incubation was done at room temperature for $2 \mathrm{~h}$ with a rabbit polyclonal anti-UHRF1 Antibody (Santa Cruz M-132: sc-98817). Membrane was washed in PBST and incubated with HRP conjugated antirabbit secondary antibody in blocking buffer. HRP conjugates were detected with enhanced chemiluminescence (ECL, Amersham Biosciences).

\section{Enzyme-linked immunosorbent assay (ELISA)}

All binding reactions were carried out in buffer $\mathrm{Z}$ containing $20 \mathrm{mM}$ TRIS HCL (pH 7.5), $150 \mathrm{mM} \mathrm{NaCl}, 20 \mathrm{mM}$ $\mathrm{KCl}, 0.02 \%$ IGEPAL and $1 \mathrm{mM}$ dithiothreitol. A Highbind Streptaplate (Roche) was blocked with $1 \times$ PBS containing $3 \%$ BSA prior reaction. Subsequently, $50 \mu \mathrm{L}$ of a $50 \mathrm{nM}$ solution of biotinylated DNA were added per well and allowed to attach for $30 \mathrm{~min}$ at $37^{\circ} \mathrm{C}$ with gentle shaking. Wells were then washed three times with buffer $Z$. The proteins were diluted in buffer $\mathrm{Z}$ and $50 \mu \mathrm{L}$ were added to each well. After incubation for $1 \mathrm{~h}$ at room temperature, plates were washed three times with buffer Z. For detection, $50 \mu \mathrm{L}$ of mouse polyclonal anti-His tag antibody (Thermo Scientific) at 1:500 dilution in buffer $\mathrm{Z}$ were added per well and incubated for $1 \mathrm{~h}$ at room temperature. After washing three times with buffer Z, a polyclonal HRP-conjugated sheep anti-Mouse IgG antibody (GE Healthcare) diluted 1:2,000 in buffer $Z$ was added and incubated for $30 \mathrm{~min}$ at room temperature. Wells were washed three times with buffer $\mathrm{Z}$ and peroxidase activity detected by adding $50 \mu \mathrm{L}$ of TACS-Sapphire (Trevigen). Reactions were stopped by the addition of $50 \mathrm{uL}$ of a $1 \mathrm{M} \mathrm{HCL}$ solution. Absorbance at $450 \mathrm{~nm}$ was measured using a SPECTROstar Nano (BMG Labtech). The equilibrium dissociation constants (Kd) for the protein-DNA interaction were determined by nonlinear regression by fitting to a hyperbolic binding curve.

\section{Purification of recombinant MPG, L3MBTL2 and ZSCAN21 from Baculovirus infected Sf9 cells}

Coding sequences for the proteins MPG, L3MBTL2 and ZSCAN21 (Source BioScience) were cloned into Gateway ${ }^{\circ}$ entry vector pENTR223.1 using SfiI restriction sites. CDS were then cloned into destination vector pDEST10 using Gateway $^{\circ}$ LR Clonase II mix (Invitrogen) and following manufacturer's instructions. Resulting vectors were used to transform MAX Efficiency DH10Bac ${ }^{\text {TM }}$ cells (Invitrogen). Positive clones were selected by blue-complementation and correct insertion of sequence of interest was confirmed by PCR. Resulting bacmids were then transfected into Sf9 cells using Cellfectin ${ }^{\odot}$ II Reagent (Invitrogen). Baculoviruses were then amplified and Sf9 cells expressing the proteins of interest were then harvested at 48, 72 and $96 \mathrm{~h}$ post infection for protein expression analysis. Cells pellets were resuspended in Lysis Buffer $\left(50 \mathrm{mM} \mathrm{NaH} \mathrm{PO}_{4}, 300 \mathrm{mM}\right.$ $\mathrm{NaCl}, 10 \mathrm{mM}$ imidazole, $1 \%$ Triton and protease inhibitors), incubated on ice for $10 \mathrm{~min}$ and centrifuged at $10,000 \times \mathrm{g}$ for $10 \mathrm{~min}$ at $4^{\circ} \mathrm{C}$. Cell lysates were filtered through a $0.2 \mu \mathrm{m}$ filter and loaded on $1 \mathrm{~mL}$ HisTrap HP column (GE Healthcare) equilibrating with buffer A (50 mM NaH $\mathrm{PO}_{4}, 300 \mathrm{mM} \mathrm{NaCl}, 20 \mathrm{mM}$ imidazole), washed with 10 column volumes of buffer A added with $40 \mathrm{mM}$ imidazole. Proteins were eluted with a gradient of $40-500 \mathrm{mM}$ imidazole over 20 column volumes. Protein samples were dialysed against storage buffer (25 mM Tris-HCl pH $7.510 \%$ glycerol, $150 \mathrm{mM} \mathrm{NaCl}$, $1 \mathrm{mM}$ DTT).

\section{Data analysis}

Spectral count values from LC-MS/MS were analysed by testing the sample groups using a non-parametric Kruskal Wallis $t$-test with a $P$ value cutoff of 0.1 , which was determined to be sufficient to identify any group where the most extreme values all fell within that group, regardless of how the values were distributed across the other groups.

\section{Gene ontology}

Functional annotation enrichment analyses were performed using The Database for Annotation, Visualization and Integrated Discovery (DAVID) v6.7 [47-49].

\section{Mass spectrometry of nucleosides}

Quantitation of nucleosides in genomic DNA was done essentially as described previously [27] except that a Q-Exactive mass spectrometer (Thermo) fitted with an UltiMate 3000 RSLCnano HPLC (Dionex) was used and one additional transition $272.1>156.0404$ (caC) was monitored. Results are expressed as \% or ppm of total unmodified and modified cytosines. 


\section{Additional files}

Additional file 1: Complete pull-down data. Excel file with table showing all proteins identified by mass spectrometry in the three replicates, with their corresponding spectral counts. Sheet 1 lists proteins identified by the Fgf15 probe, sheet 2 lists proteins identified by the Pax 6 probe.

Additional file 2: Pull-down data relative to all proteins with significant enrichment. Excel file with table showing all proteins that passed the significance test, with their corresponding spectral counts in the three replicates and $P$ value. Sheet 1 lists proteins identified by the Fgf15 probe, sheet 2 lists proteins identified by the Pax6 probe.

Additional file 3: DAVID Gene ontology analysis on proteins enriched for C, $5 \mathrm{mC}$ and $5 \mathrm{hmC}$ on the Fgf15 probe. Enrichment for $5 f C$ is shown in Figure $2 b$. Results are expressed with their corresponding Benjamini-corrected $P$ value.

Additional file 4: DAVID Gene ontology analysis on proteins enriched for $\mathrm{C}, 5 \mathrm{mC}$ and $5 \mathrm{hmC}$ on the Pax 6 probe. $5 \mathrm{fC}$ binding proteins showed no significant term enrichment. Results are expressed with their corresponding Benjamini-corrected $P$ value.

Additional file 5: Knockdown efficiency. Bar plots showing knockdown efficiency in mESC. Dark grey bars indicate mRNA levels in the knockdown samples, light grey in the control samples (transfected with non-targeting siRNA).

Additional file 6: Mass spectrometry of nucleosides data. Excel file showing mass spectrometry data from the knockdown samples (four biological replicates each)

\section{Competing interests}

The authors declare that they have no competing interests.

\section{Authors' contributions}

$\mathrm{Ml}$ and GF conceived the study and analysed the data. MI performed the experiments. DO carried out mass spectrometric analysis of pull-downs. SA performed statistical analysis. ER performed ELISA experiments. MJB helped with generation of the probes. MB analysed $5 f C$ levels by mass spectrometry. WR and SB conceived the study; MI, GF and WR wrote the manuscript. All authors have interpreted the data, read and approved the manuscript.

\section{Acknowledgments}

$\mathrm{Ml}$ is supported by the People Programme (Marie Curie Actions) of the European Union's Seventh Framework Programme FP7/2007-2013/under REA grant agreement no. 290123 and was supported by Unipharma-Graduates 7 Da Vinci Programme. MJB is supported by a BBRSC studentship. The WR lab is supported by BBSRC, MRC, the Wellcome Trust, EU EpiGeneSys and BLUEPRINT. The SB lab is supported by core funding from Cancer Research UK and a Wellcome Trust Senior Investigator Award. We would like to thank Judith Webster for the preparation of samples for mass spectrometry, Patrick Varga-Weisz and Sarah Elderkin for help with chromatography, Maureen Hamon for Baculovirus work, Phil Ewels for bioinformatic analysis.

\section{Author details}

${ }^{1}$ Epigenetics Programme, Babraham Institute, Babraham Research Campus, Cambridge CB22 3AT, UK. ${ }^{2}$ Centre for Haemato-Oncology, Barts Cancer Institute, Charterhouse Square, London EC1M 6BQ, UK. ${ }^{3}$ Proteomics Research Group, The Babraham Institute, Babraham Research Campus, Cambridge CB22 3AT, UK. ${ }^{4}$ Department of Chemistry, University of Cambridge, Lensfield Road, Cambridge CB2 1EW, UK. ${ }^{5}$ Cancer Research UK, Cambridge Research Institute, Li Ka Shing Centre, Robinson way, Cambridge CB2 ORE, UK. ${ }^{6}$ School of Clinical Medicine, The University of Cambridge, Addenbrooke's Hospital, Hills Road, Cambridge CB2 OSP, UK. 'Bioinformatics Group, Babraham Institute, Babraham Research Campus, Cambridge CB22 3AT, UK. ${ }^{8}$ Centre for Trophoblast Research, University of Cambridge, Cambridge CB2 3EG, UK. ${ }^{9}$ Wellcome Trust Sanger Institute, Cambridge CB10 1SA, UK.

Received: 17 September 2013 Accepted: 24 October 2013 Published: 24 October 2013

\section{References}

1. Ito S, D'Alessio AC, Taranova OV, Hong K, Sowers LC, Zhang Y: Role of Tet proteins in $5 \mathrm{mC}$ to $5 \mathrm{hmC}$ conversion, ES-cell self-renewal and inner cell mass specification. Nature 2010, 466:1129-1133.

2. Kriaucionis S, Heintz N: The nuclear DNA base 5-hydroxymethylcytosine is present in Purkinje neurons and the brain. Science 2009, 324:929-930.

3. Szwagierczak A, Bultmann S, Schmidt CS, Spada F, Leonhardt H: Sensitive enzymatic quantification of 5-hydroxymethylcytosine in genomic DNA. Nucleic Acids Res 2010, 38:e181.

4. Tahiliani M, Koh KP, Shen Y, Pastor WA, Bandukwala H, Brudno Y, Agarwal S, lyer LM, Liu DR, Aravind L, Rao A: Conversion of 5-methylcytosine to 5-hydroxymethylcytosine in mammalian DNA by MLL partner TET1. Science 2009, 324:930-935.

5. Khare $\mathrm{T}$, Pai $\mathrm{S}$, Koncevicius $\mathrm{K}$, Pal M, Kriukiene $\mathrm{E}$, Liutkeviciute $\mathrm{Z}$, Irimia $\mathrm{M}$, Jia PX, Ptak C, Xia MH, Tice R, Tochigi M, Morera S, Nazarians A, Belsham D, Wong AHC, Blencowe BJ, Wang SC, Kapranov P, Kustra R, Labrie V, Klimasauskas S, Petronis A: 5 -hmC in the brain is abundant in synaptic genes and shows differences at the exon-intron boundary. Nat Struct Mole Biol 2012, 19:1037-U1094.

6. Branco MR, Ficz G, Reik W: Uncovering the role of 5-hydroxymethylcytosine in the epigenome. Nat Rev Genet 2012, 13:7-13.

7. Zhu JK: Active DNA demethylation mediated by DNA glycosylases. Annu Rev Genet 2009, 43:143-166.

8. Wu SC, Zhang Y: Active DNA demethylation: many roads lead to Rome. Nat Rev Mol Cell Biol 2010, 11:607-620.

9. Jin SG, Wu X, Li AX, Pfeifer GP: Genomic mapping of 5-hydroxymethylcytosine in the human brain. Nucleic Acids Res 2011, 39:5015-5024

10. Szulwach KE, Li X, Li Y, Song CX, Wu H, Dai Q, Irier H, Upadhyay AK, Gearing M, Levey Al, Vasanthakumar A, Godley LA, Chang Q, Cheng X, He C, Jin P: 5-hmC-mediated epigenetic dynamics during postnatal neurodevelopment and aging. Nat Neurosci 2011, 14:1607-1616.

11. Spruijt CG, Gnerlich F, Smits AH, Pfaffeneder T, Jansen PW, Bauer C, Munzel M, Wagner M, Muller M, Khan F, Eberl HC, Mensinga A, Brinkman AB, Lephikov K, Muller U, Walter J, Boelens R, van Ingen H, Leonhardt H, Carell $\mathrm{T}$, Vermeulen M: Dynamic readers for 5-(hydroxy)methylcytosine and its oxidized derivatives. Cell 2013, 152:1146-1159.

12. Rando OJ: Combinatorial complexity in chromatin structure and function: revisiting the histone code. Curr Opin Genet Dev 2012, 22:148-155

13. Law JA, Jacobsen SE: Establishing, maintaining and modifying DNA methylation patterns in plants and animals. Nat Rev Genet 2010, 11:204-220

14. Deaton $A M$, Bird $A: C p G$ islands and the regulation of transcription. Genes Dev 2011, 25:1010-1022.

15. Yildirim O, Li R, Hung JH, Chen PB, Dong X, Ee LS, Weng Z, Rando OJ, Fazzio TG: Mbd3/NURD complex regulates expression of 5-Hydroxymethylcytosine marked genes in embryonic stem cells. Cell 2011, 147:1498-1510

16. Mellen M, Ayata P, Dewell S, Kriaucionis S, Heintz N: MeCP2 binds to $5 \mathrm{hmC}$ enriched within active genes and accessible chromatin in the nervous system. Cell 2012, 151:1417-1430.

17. Meehan RR, Lewis JD, McKay S, Kleiner EL, Bird AP: Identification of a mammalian protein that binds specifically to DNA containing methylated CpGs. Cell 1989, 58:499-507.

18. Ficz G, Branco MR, Seisenberger S, Santos F, Krueger F, Hore TA, Marques CJ, Andrews S, Reik W: Dynamic regulation of 5-hydroxymethylcytosine in mouse ES cells and during differentiation. Nature 2011, 473:398-402.

19. Frauer C, Hoffmann T, Bultmann S, Casa V, Cardoso MC, Antes I, Leonhardt $\mathrm{H}$ : Recognition of 5-hydroxymethylcytosine by the Uhrf1 SRA domain. PLoS One 2011, 6:e21306.

20. Bartels SJ, Spruijt CG, Brinkman AB, Jansen PW, Vermeulen M, Stunnenberg HG: A SILAC-based screen for Methyl-CpG binding proteins identifies RBP-J as a DNA methylation and sequence-specific binding protein PLoS One 2011, 6:e25884

21. Hendrich $B, B i r d A$ : Identification and characterization of a family of mammalian methyl-CpG binding proteins. Mol Cell Biol 1998, 18:6538-6547

22. Martello G, Sugimoto T, Diamanti E, Joshi A, Hannah R, Ohtsuka S, Gottgens B, Niwa H, Smith A: Esrrb is a pivotal target of the Gsk3/Tcf3 axis regulating embryonic stem cell self-renewal. Cell Stem Cell 2012, $11: 491-504$ 
23. Hashimoto $H$, Zhang $X$, Cheng $X$ : Excision of thymine and 5-hydroxymethyluracil by the MBD4 DNA glycosylase domain: structural basis and implications for active DNA demethylation. Nucleic Acids Res 2012, 40:8276-8284.

24. Illingworth RS, Gruenewald-Schneider U, Webb S, Kerr AR, James KD, Turner DJ, Smith C, Harrison DJ, Andrews R, Bird AP: Orphan CpG islands identify numerous conserved promoters in the mammalian genome. PLoS Genet 2010, 6:e1001134.

25. Raiber EA, Beraldi D, Ficz G, Burgess HE, Branco MR, Murat P, Oxley D, Booth MJ, Reik W, Balasubramanian S: Genome-wide distribution of 5 -formylcytosine in embryonic stem cells is associated with transcription and depends on thymine DNA glycosylase. Genome Biol 2012, 13:R69.

26. Song CX, Szulwach KE, Dai Q, Fu Y, Mao SQ, Lin L, Street C, Li Y, Poidevin M, Wu H, Gao J, Liu P, Li L, Xu GL, Jin P, He C: Genome-wide profiling of 5 -formylcytosine reveals its roles in epigenetic priming. Cell 2013, 153:678-691.

27. Shen $L, W u H$, Diep D, Yamaguchi S, D'Alessio AC, Fung HL, Zhang K, Zhang Y: Genome-wide analysis reveals TET- and TDG-dependent 5-methylcytosine oxidation dynamics. Cell 2013, 153:692-706.

28. Ficz G, Hore TA, Santos F, Lee HJ, Dean W, Arand J, Krueger F, Oxley D, Paul YL, Walter J, Cook SJ, Andrews S, Branco MR, Reik W: FGF Signaling Inhibition in ESCs Drives Rapid Genome-wide Demethylation to the Epigenetic Ground State of Pluripotency. Cell Stem Cell 2013, 13:351-359.

29. Maiti A, Drohat AC: Thymine DNA glycosylase can rapidly excise 5-formylcytosine and 5-carboxylcytosine: potential implications for active demethylation of CpG sites. J Biol Chem 2011, 286:35334-35338.

30. Hashimoto H, Hong S, Bhagwat AS, Zhang X, Cheng X: Excision of 5-hydroxymethyluracil and 5-carboxylcytosine by the thymine DNA glycosylase domain: its structural basis and implications for active DNA demethylation. Nucleic Acids Res 2012, 40:10203-10214.

31. Frauer $C$, Rottach A, Meilinger D, Bultmann S, Fellinger K, Hasenoder $S$, Wang M, Qin W, Soding J, Spada F, Leonhardt H: Different binding properties and function of CXXC zinc finger domains in Dnmt1 and Tet1. PLoS One 2011, 6:16627.

32. Zhang $H$, Zhang $X$, Clark E, Mulcahey M, Huang S, Shi YG: TET1 is a DNAbinding protein that modulates DNA methylation and gene transcription via hydroxylation of 5-methylcytosine. Cell Res 2010, 20:1390-1393.

33. Xu Y, Wu F, Tan L, Kong L, Xiong L, Deng J, Barbera AJ, Zheng L, Zhang H, Huang S, Min J, Nicholson T, Chen T, Xu G, Shi Y, Zhang K, Shi YG: Genome-wide regulation of $5 \mathrm{hmC}, 5 \mathrm{mC}$, and gene expression by Tet 1 hydroxylase in mouse embryonic stem cells. Mol Cell 2011, 42:451-464.

34. Fujii Y, Nakamura M: FOXK2 transcription factor is a novel G/T-mismatch DNA binding protein. J Biochem 2010, 147:705-709.

35. Gabut M, Samavarchi-Tehrani P, Wang X, Slobodeniuc V, O'Hanlon D, Sung HK, Alvarez M, Talukder S, Pan Q, Mazzoni EO, Nedelec S, Wichterle H, Woltjen K, Hughes TR, Zandstra PW, Nagy A, Wrana JL, Blencowe BJ: An alternative splicing switch regulates embryonic stem cell pluripotency and reprogramming. Cell 2011, 147:132-146.

36. Chokas AL, Trivedi CM, Lu MM, Tucker PW, Li S, Epstein JA, Morrisey EE: Foxp1/2/4-NuRD interactions regulate gene expression and epithelial injury response in the lung via regulation of interleukin-6. J Biol Chem 2010, 285:13304-13313.

37. Shi X, Wallis AM, Gerard RD, Voelker KA, Grange RW, DePinho RA, Garry MG Garry DJ: Foxk1 promotes cell proliferation and represses myogenic differentiation by regulating Foxo4 and Mef2. J Cell Sci 2012, 125:5329-5337.

38. Noce T, Fujiwara Y, Sezaki M, Fujimoto H, Higashinakagawa T: Expression of a mouse zinc finger protein gene in both spermatocytes and oocytes during meiosis. Dev Biol 1992, 153:356-367.

39. Chowdhury K, Goulding M, Walther C, Imai K, Fickenscher H: The ubiquitous transactivator $\mathrm{Zfp}-38$ is upregulated during spermatogenesis with differential transcription. Mech Dev 1992, 39:129-142.

40. Watanabe S, Ichimura T, Fujita N, Tsuruzoe S, Ohki I, Shirakawa M, Kawasuji M, Nakao M: Methylated DNA-binding domain 1 and methylpurine-DNA glycosylase link transcriptional repression and DNA repair in chromatin. Proc Natl Acad Sci U S A 2003, 100:12859-12864

41. Ogawa H, Ishiguro K, Gaubatz S, Livingston DM, Nakatani Y: A complex with chromatin modifiers that occupies E2F- and Myc-responsive genes in G0 cells. Science 2002, 296:1132-1136.

42. Trojer P, Cao AR, Gao Z, Li Y, Zhang J, Xu X, Li G, Losson R, Erdjument-Bromage $H$, Tempst P, Farnham PJ, Reinberg D: L3MBTL2 protein acts in concert with PcG protein-mediated monoubiquitination of $\mathrm{H} 2 \mathrm{~A}$ to establish a repressive chromatin structure. Mol Cell 2011, 42:438-450.
43. Ito S, Shen L, Dai Q, Wu SC, Collins LB, Swenberg JA, He C, Zhang Y: Tet proteins can convert 5-methylcytosine to 5 -formylcytosine and 5-carboxylcytosine. Science 2011, 333:1300-1303.

44. Webster J, Oxley D: Peptide mass fingerprinting: protein identification using MALDI-TOF mass spectrometry. Methods Mol Biol 2005, 310:227-240.

45. The ProteomeXchange consortium. http://proteomecentral.proteomexchange.org.

46. Vizcaino JA, Cote RG, Csordas A, Dianes JA, Fabregat A, Foster JM, Griss J, Alpi E, Birim M, Contell J, O'Kelly G, Schoenegger A, Ovelleiro D, Perez-Riverol Y, Reisinger F, Rios D, Wang R, Hermjakob H: The PRoteomics IDEntifications (PRIDE) database and associated tools: status in 2013. Nucleic Acids Res 2013, 41:D1063-D1069.

47. da Huang W, Sherman BT, Lempicki RA: Systematic and integrative analysis of large gene lists using DAVID bioinformatics resources. Nat Protoc 2009, 4:44-57.

48. da Huang W, Sherman BT, Lempicki RA: Bioinformatics enrichment tools: paths toward the comprehensive functional analysis of large gene lists. Nucleic Acids Res 2009, 37:1-13.

49. The Database for Annotation, Visualization and Integrated Discovery (DAVID) v6.7. http://david.abcc.ncifcrf.gov/home.jsp.

doi:10.1186/gb-2013-14-10-r119

Cite this article as: lurlaro et al: A screen for hydroxymethylcytosine and formylcytosine binding proteins suggests functions in transcription and chromatin regulation. Genome Biology 2013 14:R119.

\section{Submit your next manuscript to BioMed Central and take full advantage of:}

- Convenient online submission

- Thorough peer review

- No space constraints or color figure charges

- Immediate publication on acceptance

- Inclusion in PubMed, CAS, Scopus and Google Scholar

- Research which is freely available for redistribution

Submit your manuscript at www.biomedcentral.com/submit
C Biomed Central 